\title{
X-linked lymphoproliferative disease
}

\author{
INSERM
}

\section{Source}

INSERM. (1999). Orphanet: an online rare disease and orphan drug data base. $\underline{X \text {-linked }}$ lymphoproliferative disease. ORPHA:2442

X-linked lymphoproliferative disease is a hereditary immunodeficiency characterized, in the majority of cases, by an inadequate immune response to infection with the EpsteinBarr virus (EBV). 